\title{
COTTUS GOBIO LINNAEUS, 1758, ECOLOGICAL STATUS AND MANAGEMENT ELEMENTS IN MARAMUREŞ MOUNTAINS NATURE PARK (ROMANIA)
}

\author{
Angela, CURTEAN-BĂNĂDUC ${ }^{1}$, Oana, DANCI ${ }^{2}$, Răzvan, VOICU ${ }^{3}$ and Doru, BĂNĂDUC ${ }^{4}$ \\ 1 "Lucian Blaga" University of Sibiu, Sibiu, Romania, angela.banaduc@ulbsibiu.ro \\ 2 "Lucian Blaga" University of Sibiu, Sibiu, Romania, oanadanci@gmail.com \\ ${ }^{3}$ National Institute of Hydrology and Water Management, Bucureşti, Romania, RO-013686, rzvnvoicu@yahoo.com \\ 4 "Lucian Blaga" University of Sibiu, Sibiu, Romania, ad.banaduc@yahoo.com
}

\begin{abstract}
Cottus gobio is considered a fish species of conservation concern within the Vişeu Watershed. The habitats state, usually populated by Cottus gobio within the Maramureş Mountains Nature Park (Vişeu and Bistriţa Aurie watersheds) vary among reduced $(34.42 \%)$, average $(45.91 \%)$, and good $(19.67 \%)$. The excellent conservation status is currently missing for populations of this fish in the Vișeu Basin. Human impact categories were inventoried as inducing the diminishment of Cottus gobio habitats and populations in the researched area in comparison with its natural potential are: minor riverbed morphodynamic changes, liquid and solid natural flow disruption, destruction of riparian tree and shrub vegetation, habitat fragmentation-fish populations isolation, organic/mining pollution activities, fish washing away at floods, and poaching.
\end{abstract}

KEY WORDS: Bullhead, lotic systems, fish habitats, human impact, assessment, management.

\section{INTRODUCTION}

The highland water resources are naturally of very good quality if the human impact in these areas are not significant (Romanescu, 2016), and do not induce instable ecologic conditions (Schneider-Binder, 2017), the impact of human activities needs to be evaluated and monitored in the local protected species and habitats circumstances. Fish are one of the most well known taxonomic groups which are affected by different types of human impact (Năvodaru and Năstase, 2006; Bănăduc et al., 2011; Florea, 2017; Khoshnood, 2017).

\section{STUDY AREA AND METHODS}

Lotic ecosystems of the Maramures Mountains Nature Park area belong mainly to the Vișeu River watershed (Fig. 1) and are very limited to the Bistrita Aurie River watershed, in northern Romania (Fig. 2). The Vișeu River watershed is neighboured by the Maramureș Mountains in the northeastern area, by the Maramureș Hills in the west and southwest parts, and by Rodna Mountains in its southeast part. The area with the lowest altitude of this watershed is at $303 \mathrm{~m}$ above the sea level where the Vişeu River is at the confluence with the Tisa River, while the highest altitude is $2,303 \mathrm{~m}$ in the Rodna Mountains (Pietrosul Rodnei Peak). Due to the geographical variety within this watershed, the researched area is varied in landscapes, and characterised by a relatively high diversity of biotopes, biocoenosis, and among others, fish species. (Curtean-Bănăduc et al., 2008; Bănăduc et al., 2011)

With a length of $80 \mathrm{~km}$, a watershed of $1,606 \mathrm{~km}^{2}$ and a maximum multiannual average flow of $30.7 \mathrm{~m}^{3} / \mathrm{s}$ at its lowest sector, the Vişeu River is a second degree tributary of the Danube River, confluencing into the much biger Tisa River. It springs in the Prislop Pass $(1,416 \mathrm{~m})$ and it confluence with the Tisa River near the Valea Vișeului Village. In its highland area, from the springs to the Moisei locality, the Vișeu River has an appreciable average slope $(20-50 \mathrm{~m} / \mathrm{km})$, under the name Borșa or Vișeuț. The Vișeu River enters the Moisei locality in the Maramureș Depression where its valley is larger, with the exception of a few narrow gorge-like sectors such as the Rădeasa Oblaz, and Vișeu gorges. The Vișeu River hydrographical characteristics belong to the EasternCarpathian-Moldavian type in its highland part and of EasternCarpathian-Transylvanian type in its lower sector. This river discharge is important, at $39.4 \%$ of the annual discharge in the spring season, a $27 \%$ decline in the summer, $18.6 \%$ during autumn, and its minimum $15 \%$ in winter. (Curtean-Bănăduc et al., 2008; Bănăduc et al., 2011)

The most important Rodna-springing lotic systems of the Vişeu Watershed are the following: Fântânilor Valley (seven $\mathrm{km}$ length), Negoiasa Valley (six km), Repedea Valley (10 km), Pietroasa Valley (seven $\mathrm{km}$ ), Vremeșu Valley, Hotarului Stream, Dragoș's Valley $(11 \mathrm{~km})$ and Izvorul Negru (seven $\mathrm{km}$ ). Springing from the Maramures Mountains, the right side tributaries are the following: Hășmașul Mic, Cercănel $(11 \mathrm{~km})$, Țâşla $(20 \mathrm{~km})$, Vaser (52 km), Novăț (16 km), Ruscova (39 km), Socolău (13 km), Repedea $(19 \mathrm{~km})$, Bardi $(11 \mathrm{~km})$, Covașnița $(11 \mathrm{~km})$, Frumușeaua $(14 \mathrm{~km})$ and Bistra (nine km). From the Maramureș Hills spring, there are much smaller, leftside tributaries,: Drăguiasa, Cocicoi, Spinului, Plăiuț, Neagră and Luhei. (Curtean-Bănăduc et al., 2008; Bănăduc et al., 2011)

The diversity of lotic habitats and their connected aquatic and semi-aquatic species of national and international conservation interest from the Vișeu Watershed are also 15 
diverse and vital under conservation circumstances. The fish species of this research are the same, as noted and published by various ichthyologists in the last century of specific ichthyologic studies (Bănărescu, 1964; Staicu et al., 1998; Telcean and Bănărescu, 2002; Curtean-Bănăduc et al., 2008). Half of the local fish species are of important conservation significance.
Cottus gobio Linnaeus, 1758, is one of the most important valuable fish species, where populations within the researched area have diminished in the last decades. The dispersion and ecolgical state of this threatened fish species are not exactly known and present data for proper management of Cottus gobio is necesary.

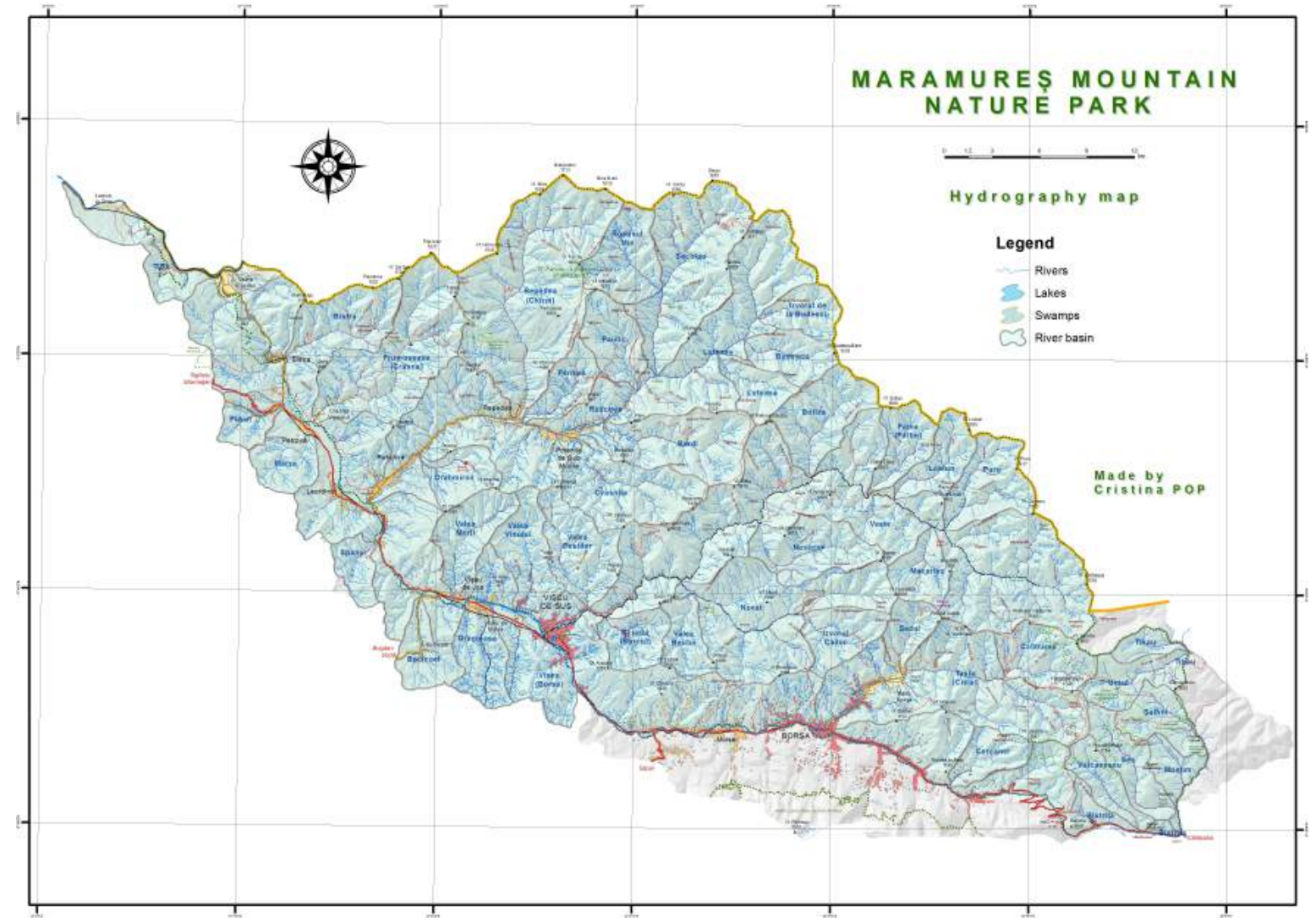

Figure 1. Vişeu River Watershed and sub-watersheds in the Maramureş Mountains Nature Park (MMNP management plan 2017).

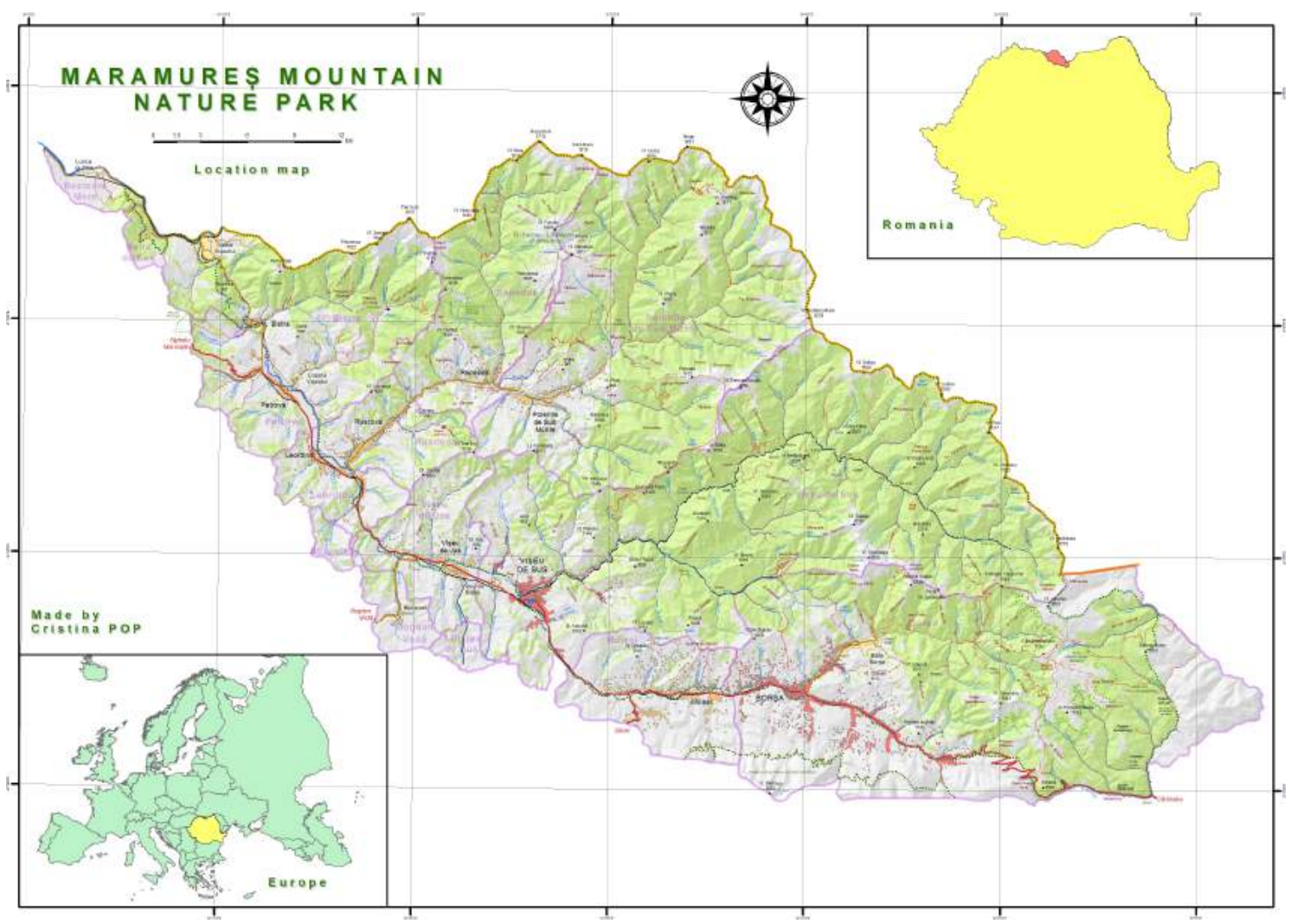

Figure 2. Maramureş Mountains Nature Park location (MMNP management plan 2017). 


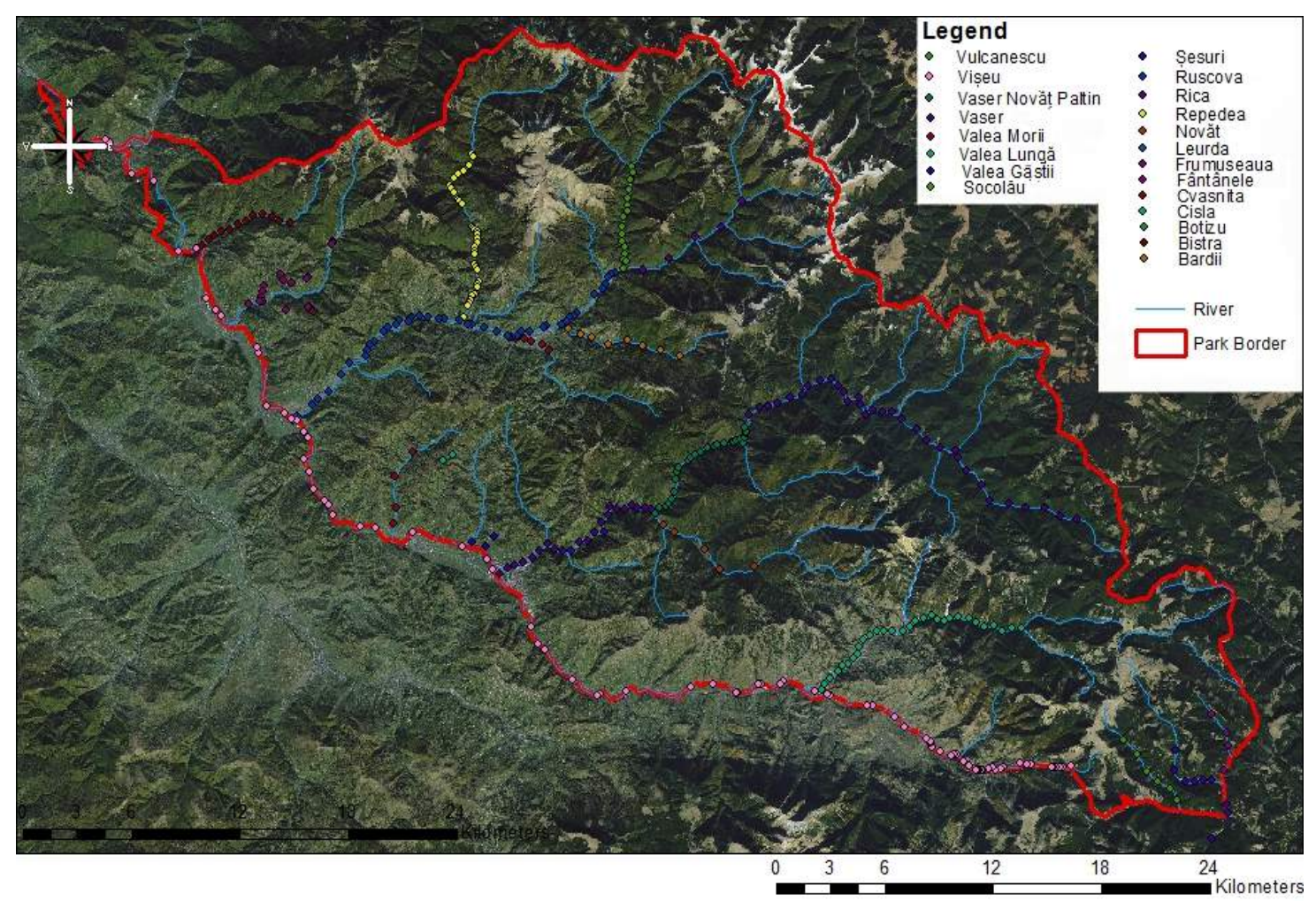

Figure 3. The total 370 sampling stations in Maramureş Mountains Nature Park.

The Cottus gobio populations study was performed from 20072017, and was based on 370 sampling sectors, (Fig. 3). This species was found in 61 stations (Tab. 1), included in the mapping of populations, assessment of the conservation status, and identification of the anthropogenic elements which affect these species.

To assess the conservation status and the populations' ecological state of Cottus gobio within the Maramureş Mountains Nature Park, quantitative samples were taken from sampling stations of approximately three kilometres between two consecutive sectors on all lotic systems with suitable habitats for the fish. The position of these stations allows for the assessment of the negative effects of human activities on the studied populations, including: minor riverbed morphodynamic changes, liquid and solid natural flow disruption, destruction of the riparian tree and shrub vegetation, habitat fragmentation-fish populations isolation, organic/mining pollution activities, fish washing away at floods, and poaching.

Quantitative sampling of the fish was realised based on electronarcosis, per unit of time and effort per sampling section (two hours on Vişeu River, one hour on Vaser, Ruscova and Frumuşeaua rivers, 30 minutes on other rivers of the references zone - Repedea, Novăţ, Şesuri, Fântânele, Bistra, Socolău) on five longitudinal sections of $100 \mathrm{~m}$ length. After species identification and counting individuals, the sampled fish were released in their natural habitat.

The number of fish sampled in the unity of time and effort can be converted through correspondence in some categories like: (C) - common fish species, (R) - rare, or (V) - very rare, according to the Natura 2000 standard data form for filling guidelines, "In mammals, amphibians, reptiles and fishes, no numeric information can be indicative and then the size/density of the population is evaluated as (C) - common species, (R) - rare species, or (V) - very rare species".
There were different criteria to evaluate the studied populations' status: size of populations, balanced distribution of individuals by age classes, distribution areal size and the percentage of fish individuals of Cottus gobio in the local fish associations.

According to the Natura 2000 guidelines, the standard data form filling is based on the following criteria: "The conservation degree of specific habitats," contain the subcriteria: i) the degree of conservation of the habitat features which are important for the species; ii) possibilities for recovery.

The criteria i) needs a comprehensive assessment of the characteristics of the habitat regarding the needs of the species of interest. "The best expertise" is used to rank this criterion in the following way: I. elements in excellent condition, II. well preserved elements, III. elements in average or partially degraded conditions.

In the cases in which the subclass I is granted, "I: elements in excellent condition" or "II: well preserved elements," the criteria B (b) should be classified entirely as "A: excellent conservation" or "B: good conservation" regardless of the other sub-criterion classification.

In the case of this sub-criterion ii) which is taken into account only if the items are partially degraded, an evaluation of the viability of the analysed population is necessary. The obtained ranking system is: I. easy recovery; II. restoration possible with average effort; III. restoration difficult or impossible.

The combination used for classification is based on two subcriteria: A - excellent conservation = elements in excellent condition, regardless of classification of recovery possibility; B - very good conservation $=$ well preserved elements, regardless of classification of recovery possibility; B - good conservation $=$ average or partially degraded condition and easy to restore; $\mathrm{C}-$ average or reduced conservation $=$ all other combinations. ${ }_{17}$ 
In every sampled sector, the following were assessed: condition, pressures/threats of habitats and populations of Cottus gobio.

The sampling sections to evaluate fish population and the conservation status of Cottus gobio in the study area appear in sectors where the populations are permanent, with a good conservation status and well preserved specific habitats; also as in lotic sectors situated at the edge of the distribution area for the studied species, which contain sectors under human activities impact that can put the researched populations statethe Representativity Criteria.

Cottus gobio Linnaeus 1758 (Fig. 4) (Actinopterygii, Scorpaeniformes, Cottidae), was sampled in the study area in the last century (Bănărescu, 1964, Staicu et al., 1998; CurteanBănăduc et al., 2008).

This species is often confused in the area with Cottus poecilopus, but has distinctive identification elements. This species has an elongated and thick body. The profile is slightly convex between the tip of the snout and the eyes, the back is almost horizontal, and the head is just a little lower than the body. The head is big, dorso-ventral flattened and thicker than the body. The eyes are situated in the anterior part of the head, semi-spherical, looking upward. The superior part of the eye is often covered by a pigmented eyelid, easy to be confused with the skin. They also have two pairs of small, distanced and simple nostrils; the anterior pair is situated far in the front of the eyes. The inter-orbitary space is slightly holed. The snout is rounded. The mouth is big and terminal, its ends reach an under eye position or near this area. The teeth are small and the caudal peduncle is laterally compressed. The dorsal fins are close, the first is low with a convex edge, the second with a plain edge. The anal fin is inserted a little after the second dorsal fin insertion. The pectoral fins are big and broad, and their tips usually reach or overdraw the anus. The caudal fin has a convex edge, sometimes almost plain. The lateral line is complete, on the middle of the caudal peduncle, when it reaches the caudal fin base. The dorsal part of the body is brown with marbled-like spots. The ventral part of the body is light-yellowish or white. In the posterior part of the body there are 3-4 dark transversal lines. The dorsal, caudal and pectoral fins have brown spots distributed in longitudinal lines. The anal and ventral fins are not spotted. It can reach $13 \mathrm{~cm}$ length (Bănărescu and Bănăduc, 2007).

This species lives in warm, mountainous lotic freshwater, and it is rare in lakes. They are usually demersal, they stay under rocks, in the sectors with not deep and relatively slow water. Sexual maturity is reached at two years old. Its reproduction occurs in March - April. Its food consists of insect larvae, amphipoda, roes and alevines. (Bănărescu and Bănăduc, 2007) Results

The stream and river sectors where Cottus gobio (Fig. 4) was sampled during the research are presented in table 1 (Fig. 5), together with the catch index values (individuals number per time and effort unit).

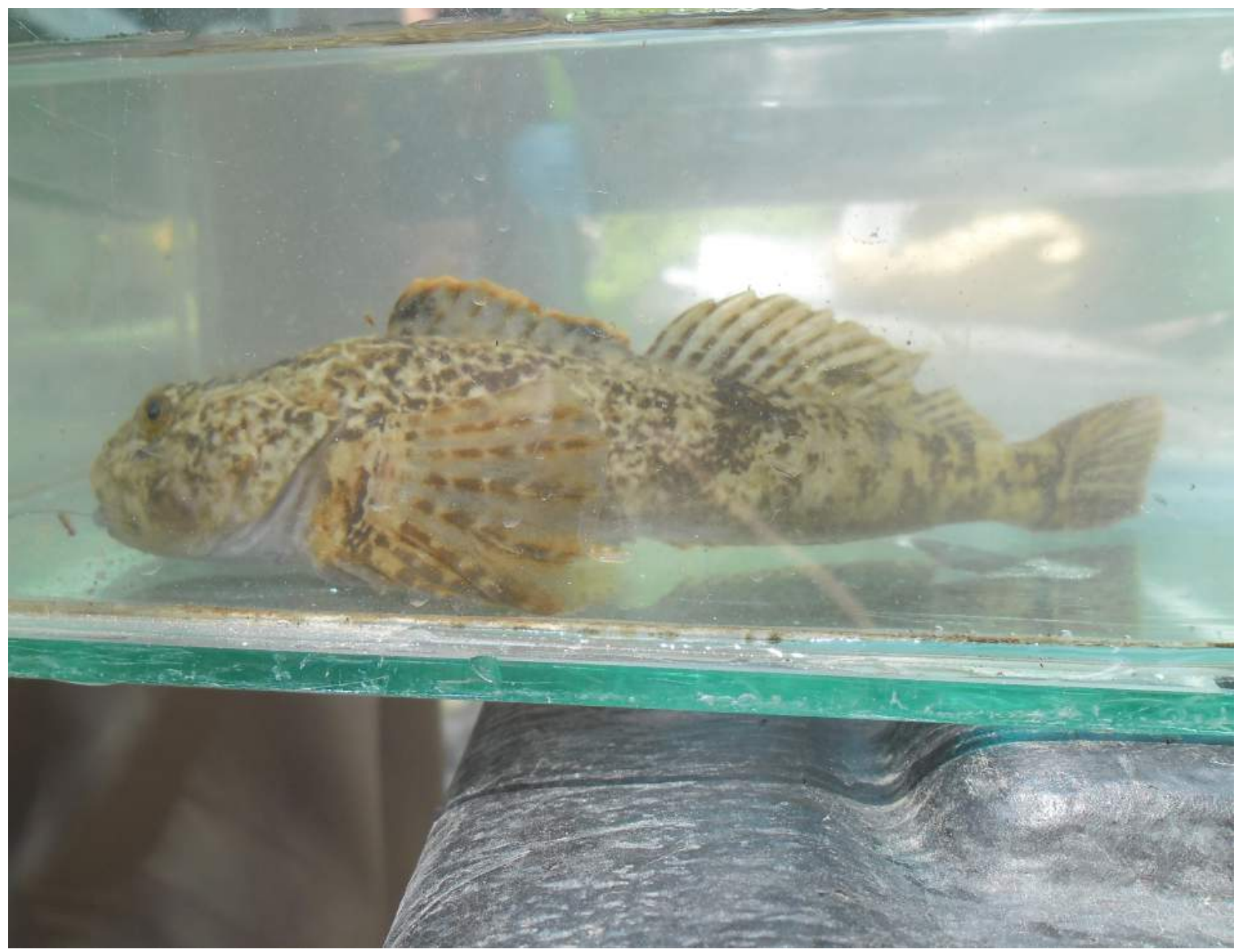

Figure 4. Sampled Cottus gobio Linnaeus 1758. 


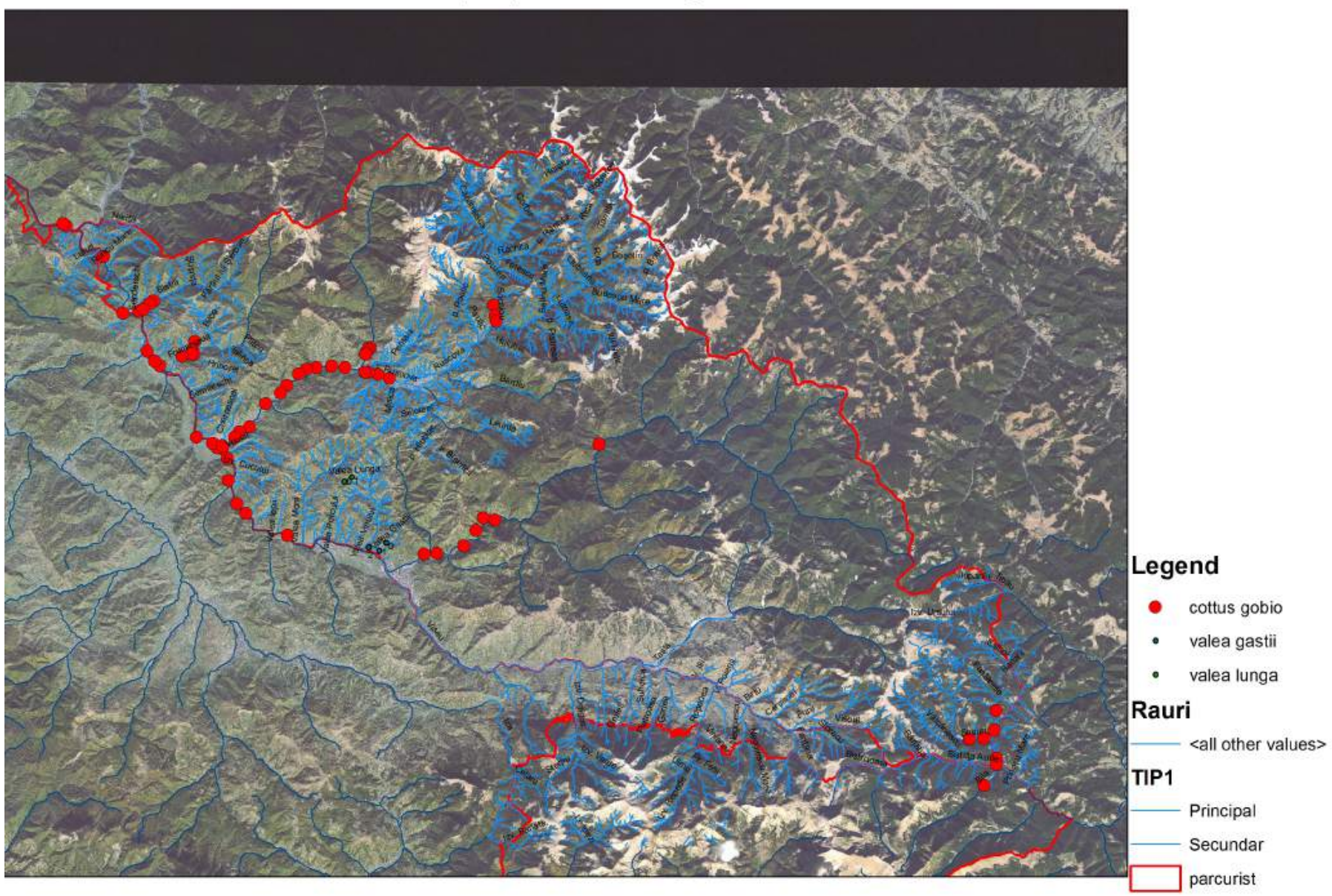

Figure 5. Sampling stations location where Cottus gobio was found.

Table 1. Cottus gobio sampling points in Maramureș Mountains Nature Park.

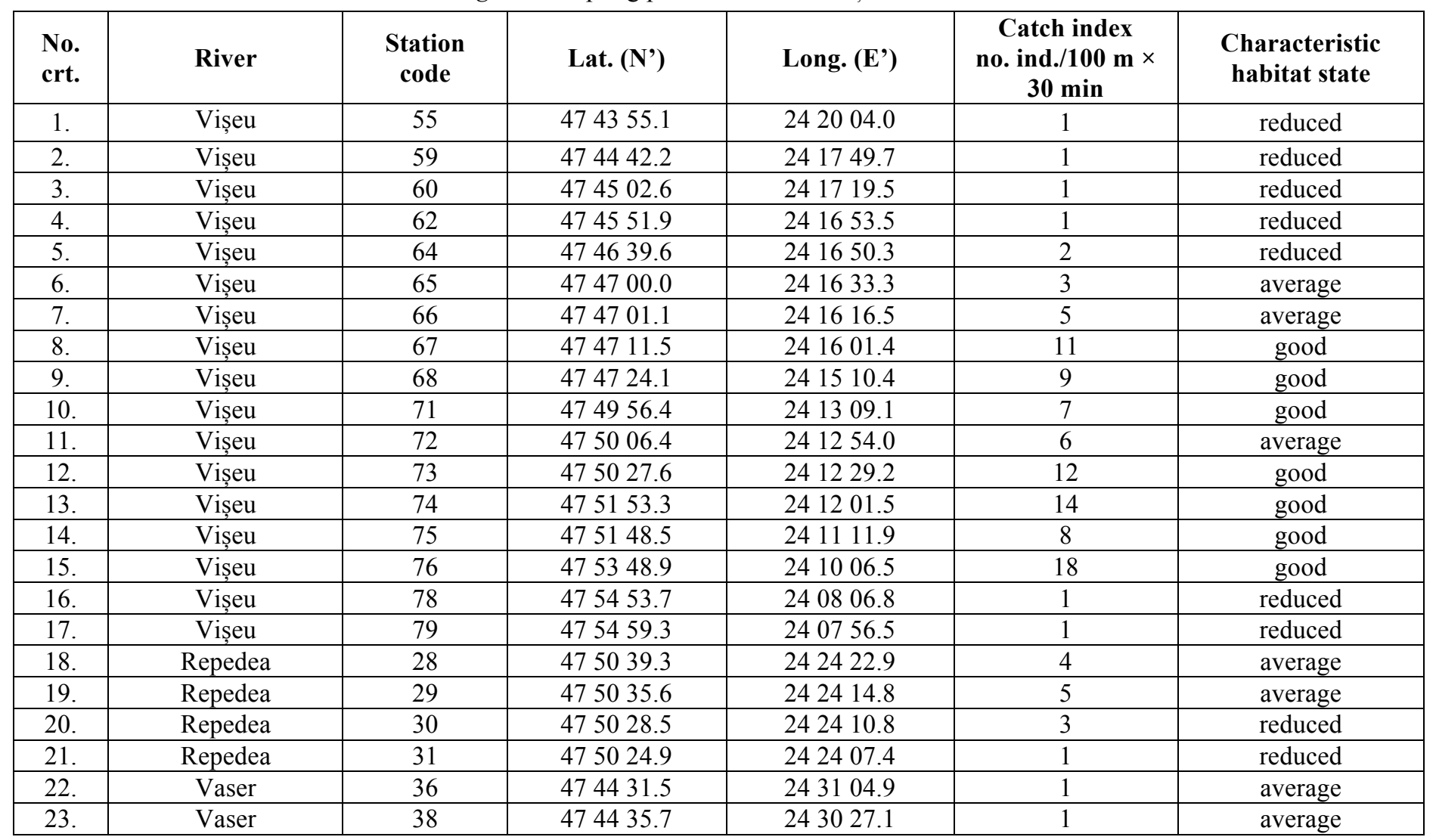




\begin{tabular}{|c|c|c|c|c|c|c|}
\hline $\begin{array}{l}\text { No. } \\
\text { crt. }\end{array}$ & River & $\begin{array}{l}\text { Station } \\
\text { code }\end{array}$ & Lat. (N') & Long. (E') & $\begin{array}{c}\text { Catch index } \\
\text { no. ind./100 } \mathrm{m} \times \\
\mathbf{3 0} \mathrm{min} \\
\end{array}$ & $\begin{array}{l}\text { Characteristi } \\
\text { habitat state }\end{array}$ \\
\hline 24. & Vaser & 40 & 474408.9 & 243004.5 & 1 & average \\
\hline 25. & Vaser & 43 & 474335.9 & 242926.2 & 5 & average \\
\hline 26. & Vaser & 47 & 474319.7 & 242759.6 & 7 & average \\
\hline 27. & Vaser & 49 & 474317.9 & 242719.4 & 2 & average \\
\hline 28. & Novăț & 31 & 474715.0 & 243635.7 & 1 & average \\
\hline 29. & Ruscova & 19 & 474934.5 & 242524.2 & 5 & reduced \\
\hline 30. & Ruscova & 20 & 474942.3 & 242447.6 & 7 & average \\
\hline 31. & Ruscova & 21 & 474946.2 & 242416.6 & 6 & average \\
\hline 32. & Ruscova & 22 & 474946.8 & 242405.6 & 9 & average \\
\hline 33. & Ruscova & 24 & 474955.7 & 242301.4 & 4 & average \\
\hline 34. & Ruscova & 26 & 474959.7 & 242219.8 & 2 & average \\
\hline 35. & Ruscova & 29 & 474955.4 & 242131.1 & 5 & average \\
\hline 36. & Ruscova & 31 & 474951.9 & 242100.5 & 7 & average \\
\hline 37. & Ruscova & 33 & 474942.0 & 242034.1 & 8 & average \\
\hline 38. & Ruscova & 35 & 474917.0 & 241957.5 & 2 & reduced \\
\hline 39. & Ruscova & 37 & 474900.0 & 241937.7 & 1 & reduced \\
\hline 40. & Ruscova & 39 & 474837,7 & 241850.2 & 1 & reduced \\
\hline 41. & Ruscova & 41 & 474747.9 & 241758.6 & 1 & reduced \\
\hline 42. & Ruscova & 42 & 474736.1 & 241726.6 & 1 & reduced \\
\hline 43. & Ruscova & 43 & 474724.9 & 241711.5 & 2 & reduced \\
\hline 44. & Ruscova & 44 & 474706.1 & 241632.1 & 1 & reduced \\
\hline 45. & Frumușeaua & 12 & 475049.5 & 241501.1 & 1 & reduced \\
\hline 46. & Frumușeaua & 14 & 475031.4 & 241455.8 & 4 & average \\
\hline 47. & Frumușeaua & 16 & 475021.7 & 241459.6 & 7 & average \\
\hline 48. & Frumușeaua & 17 & 475022.9 & 241451.5 & 6 & average \\
\hline 49. & Frumușeaua & 18 & 475016.6 & 241421.3 & 1 & reduced \\
\hline 50. & Sesuri & 3 & 473646.2 & 245618.6 & 1 & average \\
\hline 51. & Șesuri & 5 & 473647.6 & 245704.7 & 5 & good \\
\hline 52. & Șesuri & 6 & 473603.9 & 245746.1 & 6 & good \\
\hline 53. & Șesuri & 7 & 473550.4 & 245746.1 & 4 & good \\
\hline 54. & Șesuri & 8 & 473506.1 & 245706.2 & 3 & good \\
\hline 55. & Fântânele & 2 & 473746.3 & 245744.6 & 1 & average \\
\hline 56. & Fântânele & 3 & 473704.4 & 245737.1 & 3 & good \\
\hline 57. & Bistra & 9 & 475215.4 & 241248.1 & 1 & reduced \\
\hline 58. & Bistra & 10 & 475208.3 & 241236.4 & 2 & average \\
\hline 59. & Bistra & 11 & 475157.0 & 241215.9 & 1 & reduced \\
\hline 60. & Socolău & 10 & 475212.0 & 243055.3 & 1 & average \\
\hline 61. & Socolău & 12 & 475149.5 & 243101.4 & 2 & average \\
\hline
\end{tabular}

\section{DISCUSSIONS}

Based on this study's outputs, correlated with Cottus gobio ecological and biological needs, the following risk elements were identified: minor riverbed morphodynamic changes, liquid and solid natural flow disruption, destruction of riparian tree and shrub vegetation, habitat fragmentation-fish populations' isolation, organic/mining pollution activities, fish washing away at floods, and poaching.

Minor riverbed morphodynamic modifications. Typical habitat needs for Cottus gobio, in conformity with its life cycle, involve a natural variation of riverbed morphodynamics. Dikes, sills, dams, roads in riverbeds, modified riverbeds, and riverbed mineral exploitation (Fig. 6) modify the liquids and solids flow dynamics, etc., and all induced changes of the natural morphodynamics of major and minor riverbeds. These modifications negatively influence the habitats needed for the life cycle stages of the Cottus gobio, which could determine the decrease in abundances of this fish species.

New and different obstacles on the lotic systems, and water resource development activities in the researched area should not be accepted by the Maramureş Mountains Nature Park Administration without relevant ichthyologic research for this specific fish species. 


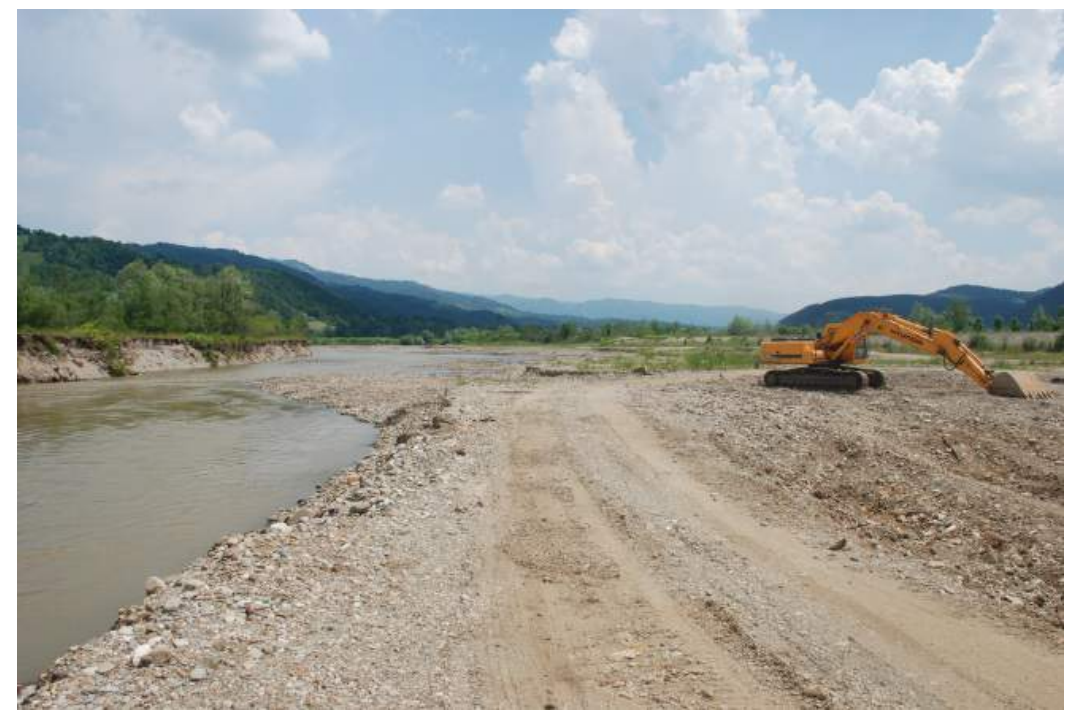

Figure 6. Overexploitation of minerals in the banks and terraces of the lower Vișeu River.

Solid and liquid natural flow modifications. The changing of natural flow and riverine morphology keep out the genesis of peculiar microhabitats, habitats, and environmental elements essential for the permanent presence of Cottus gobio. These riverbed natural morphodynamic modifications can influence the Cottus gobio population size. Anomalous happenings occur when the turbidity of water is increased due to negligent forestry activities in the more or less riverine areas, and can be a common example of human activities which cause the interruption of the solid and liquid flow natural balance.

The solid and liquid natural flow can be kept close to the local natural condition if the forestry practices and the riverbed gravel exploitations do not considerably disrupt the basin selfsustainable functions. This can be realised by harmonizing such human activities in the basin with the periods when the natural conditions are relatively similar to those to be created, (e.g. very high water turbidity induced by precipitations.)
Suggested in-channel artificial structures and changes, like dams, thresholds (Fig. 7) embankments, crossings, water extractions, bank modifications, roads in the waterbed, and thalweg changes by exploitations of construction materials from the riverbed, should not be admitted by the Maramureş Mountains Nature Park Administration without the ichtiologists agreement, based on the study of the identified local stress factors and the biological and ecological needs of Cottus gobio. In this specific study case, no crossing should be higher than $10-15 \mathrm{~cm}$ in the shallow water sectors and dry season. We also suggest a better monitoring of the forestry activities including the forbidding of dragging and storing lumber through/in the riverbeds and riverine areas. We also propose the monitoring of the development works for lumber storage and exploitation terraces, (Fig. 8) and the imperative requirement to rapid reforestation. In this context, the rotation of forest exploitations in the sub-basins of the Vișeu Basin is needed.

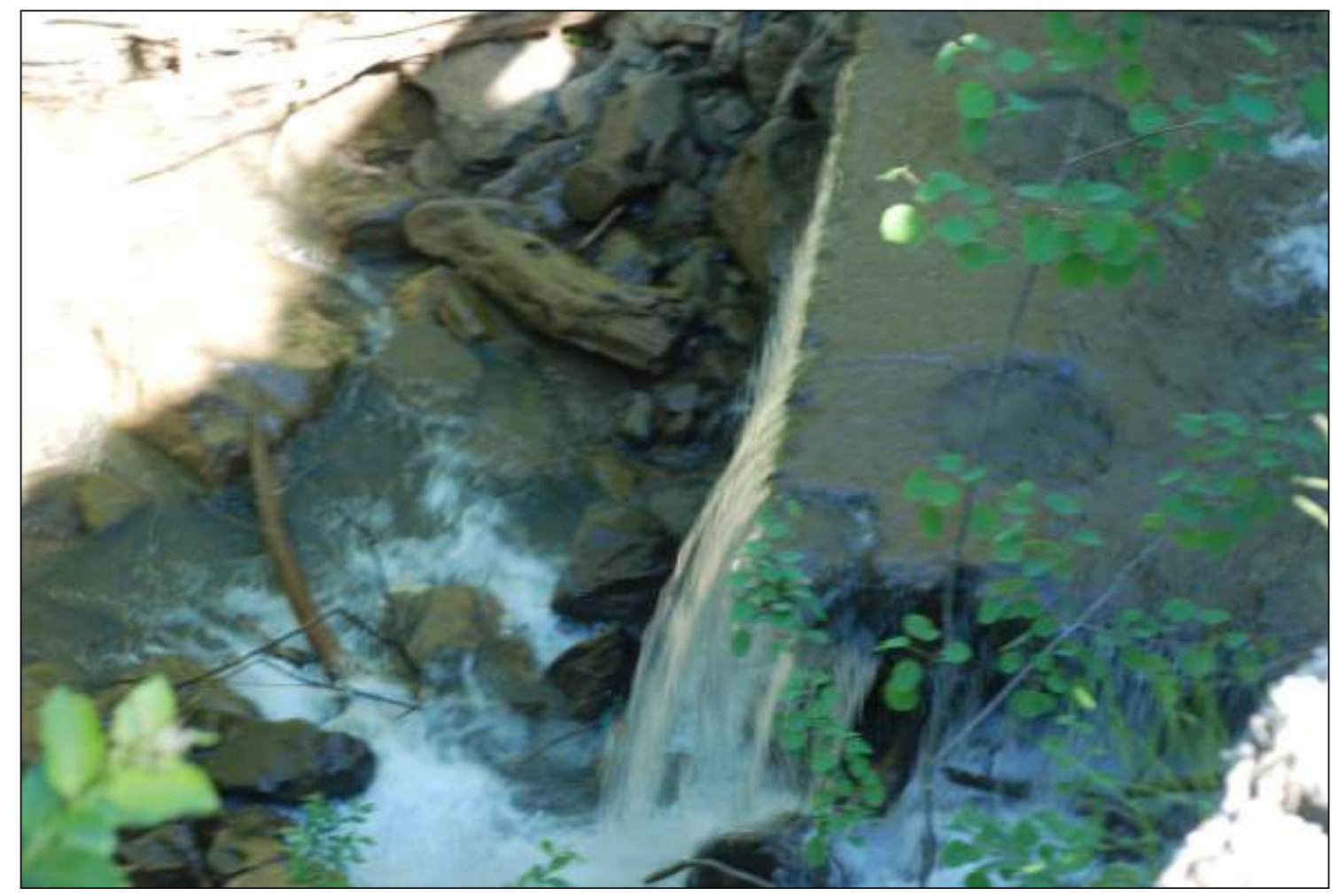

Figure 7. Concrete threshold of three m height, with no fish ladder on the upper Vişeu River. 


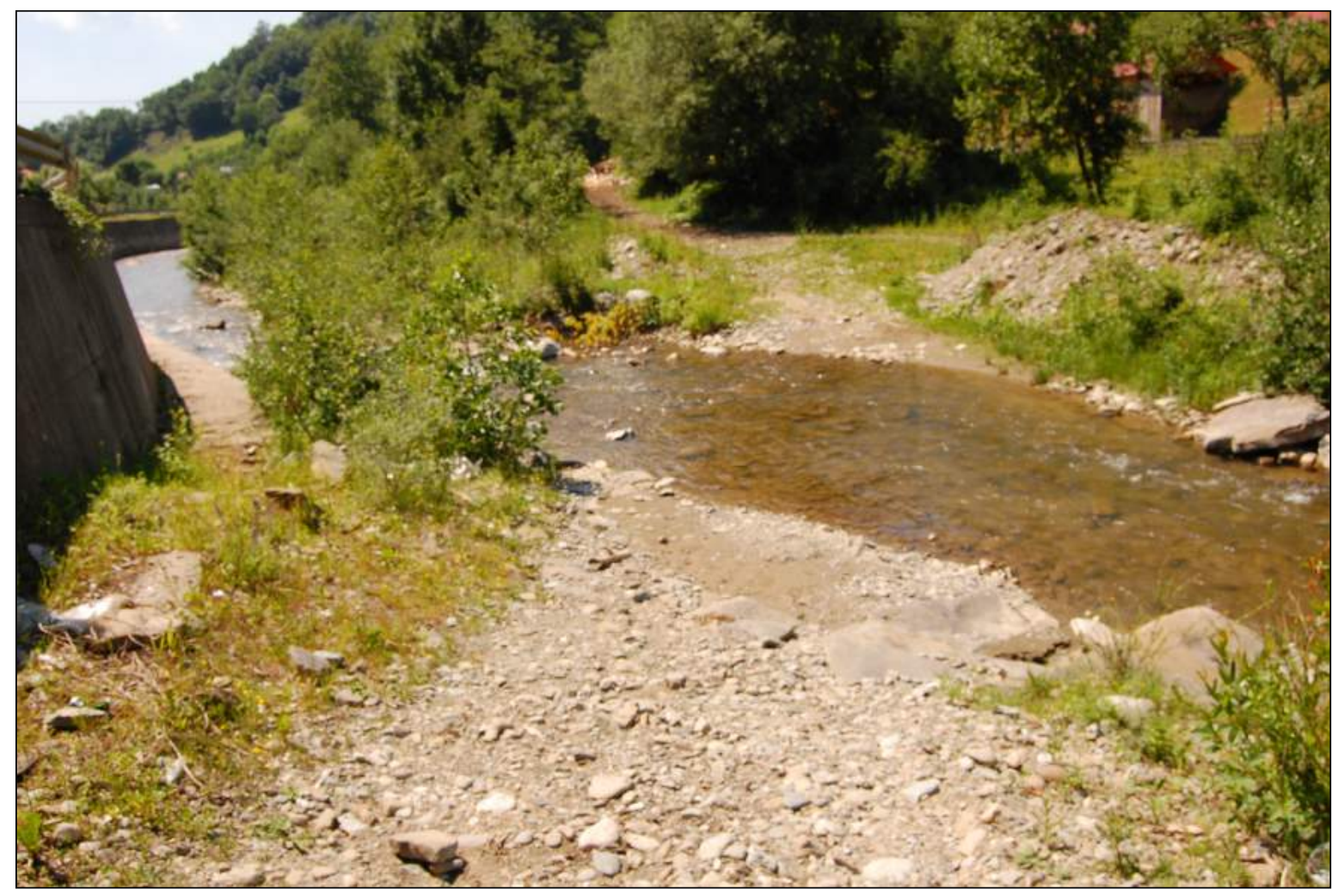

Figure 8. Frumuşeaua River concrete riverbank/completely modified and road in the riverbed.

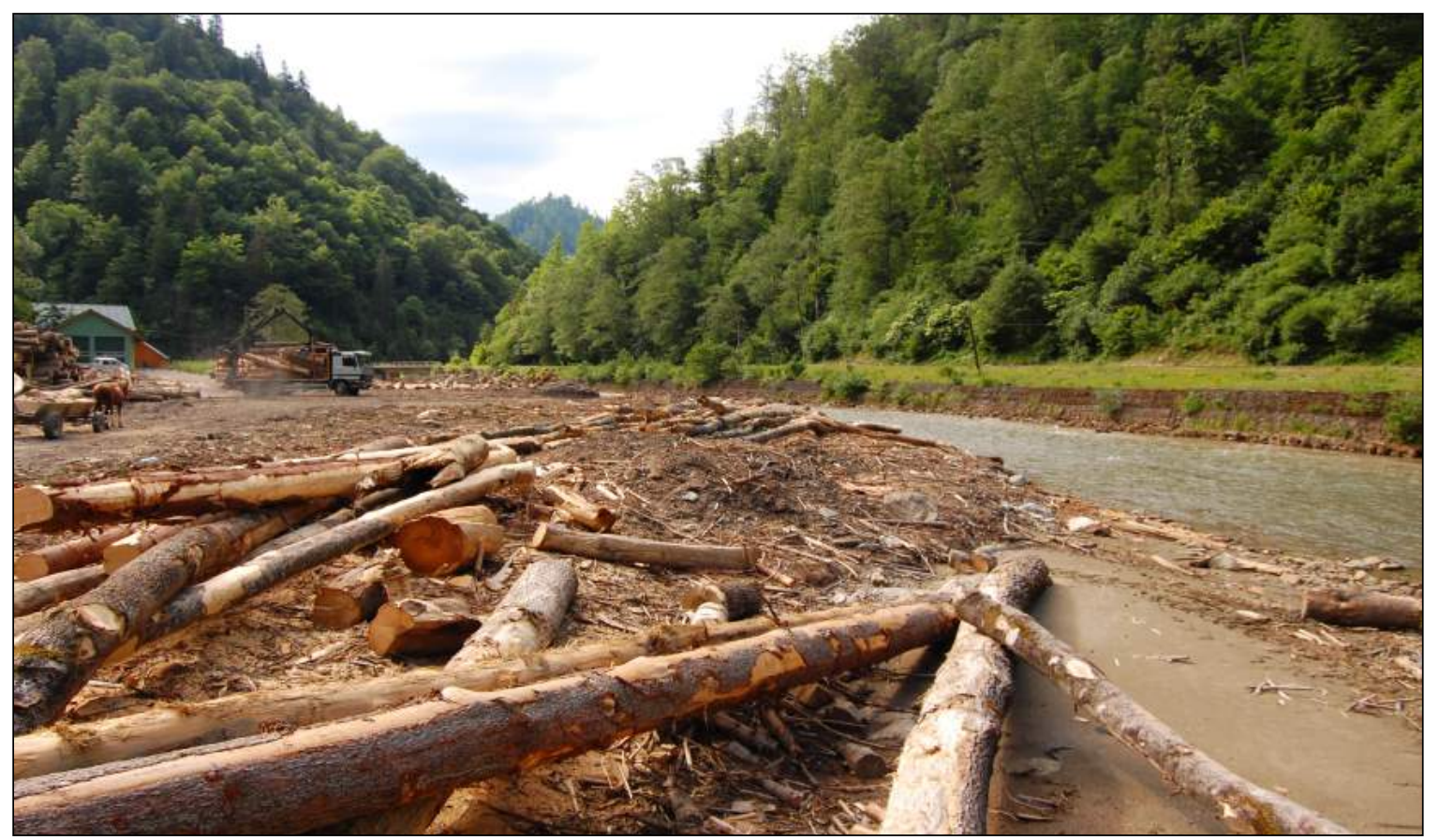

Figure 9. Logs transported and deposited on the Vaser River banks and in the riverbed.. 


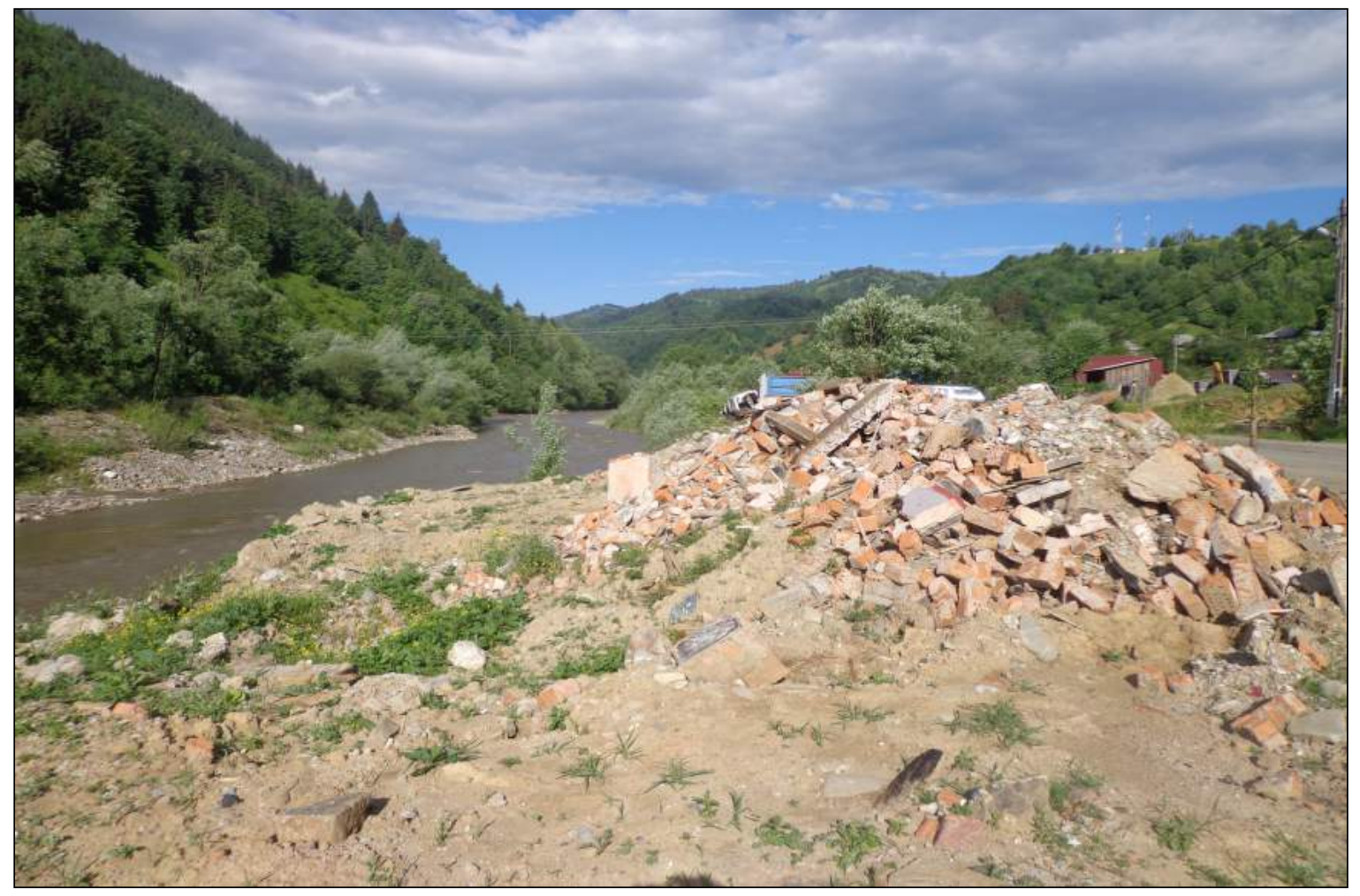

Figure 10. Destroyed riparian vegetation on the Ruscova River islet.

Destruction of riparian trees and bush vegetation. The human induced loss of islet and riparian vegetation (Fig. 9) determine a diminishment in some of the fish species abundance, including the Cottus gobio, due to negative modifications in the local in-stream microclimate and alterations of trophic resources, (Curtean-Bănăduc et al., 2014). Where possible, arboreal and riparian vegetation shrubs should be protected.

Habitat fragmentation/isolation of populations regularly push to genetic isolation, shortened gene diversity, inbreeding, and in some cases, extinction. Not blocked movement upstream and downstream in the lotic sectors, as well as proper connectivity of the distinct sub-drainage basins of the Vișeu Watershed, is an essential element for the optimum management of Cottus gobio.

The authors suggest in the context of the future economic investments in the studied basin, to be careful, as some of them can reduce or block the water course connectivity, i.e. by various crosswise obstacles in the riverbed, by decreasing the water flow or draining of some river sectors, etc.

Pollution caused by mining activities. The long time pollution provoked by mining activities for heavy metals in the T,âşla River watershednot negatively influence only the Țâșla River but also the downstream habitats and species of the upper and middle part of Viseu River. The consequence of the rain and snow water which wash the dumped mine galleries and greened refuse heaps is significant on the T,âșla River and relevant on the upstream Vișeu River.

The effects of meteoric waters which wash the dumped mine galleries and the refuse heaps into the river can be significantly decreased by insulating the old mine galleries and the refuse heaps from the Țâșla Basin.

Mixed human impacts disturb many lotic sectors in the studied areas (Figs. 10 and 11), and as a consequence, the Cottus gobio in comparison to its natural potential.
The minimal management plan for the Maramureş Mountains Nature Park area should include: buildup of lotic systems buffer zones; judicious management of water use; optimum management of sewage and waste water and surface water pollution; adjustment to different situations and conditions of the potential hydroenergetic use of the lotic systems; imposition of integrated water management at the Vișeu Watershed level; constitute and develop ecological networks; lotic systems connectivity rehabilitation; back adapted proper scientific quality evaluations and monitoring, and basin integrated management adjusted research.

Organic pollution is a continuous negative issue, sewage and wastewater treatment are connected at the same time with farm activities, mainly on the Vișeu River, and also on some of its tributaries where these human activities are present (CurteanBănduc, 2008), which is a durable stress source for fish populations. Apropriate sewage systems must be created and developed in the Vișeu Watershed and the wastewaters of all the villages and cities should be correctly treated.

Displacement of fish washed away during floods in the anthropised riverbeds and banks sectors. In the lotic sectors uniformized by human activities, fish are more often washed away during floods. In these sectors shelters should be created with a maximum high of $10-15 \mathrm{~cm}$.

Poaching. During the field study, lawless fishing was noted with electricity and diverse substances. By interrogating numerous inhabitants of the Vişeu River watershed localities, poaching is considered a permanent habit for some of the local people. The inefficiency to control this abnormal situation can induce the diminishment of the Cottus gobio individuals' numbers.

Cottus gobio is a fish species of significant conservation concern within the Vișeu Watershed. Its habitats state within the Maramureş Mountains Nature Park vary among reduced (34.42\%), average (45.91\%), and good (19.67\%). 


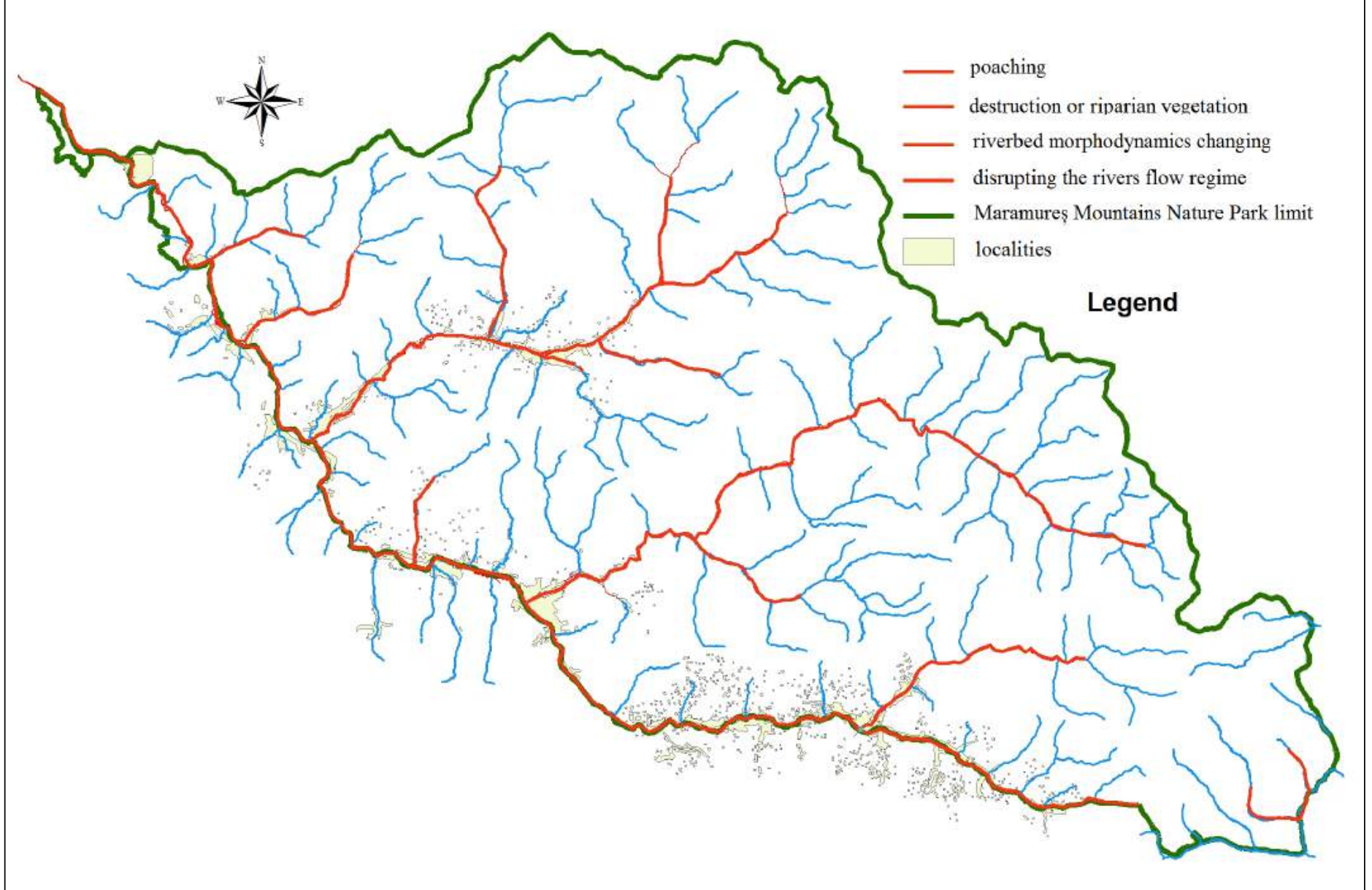

Figure 11. Identified mixed pressures and threats for Cottus gobio in the studied area.

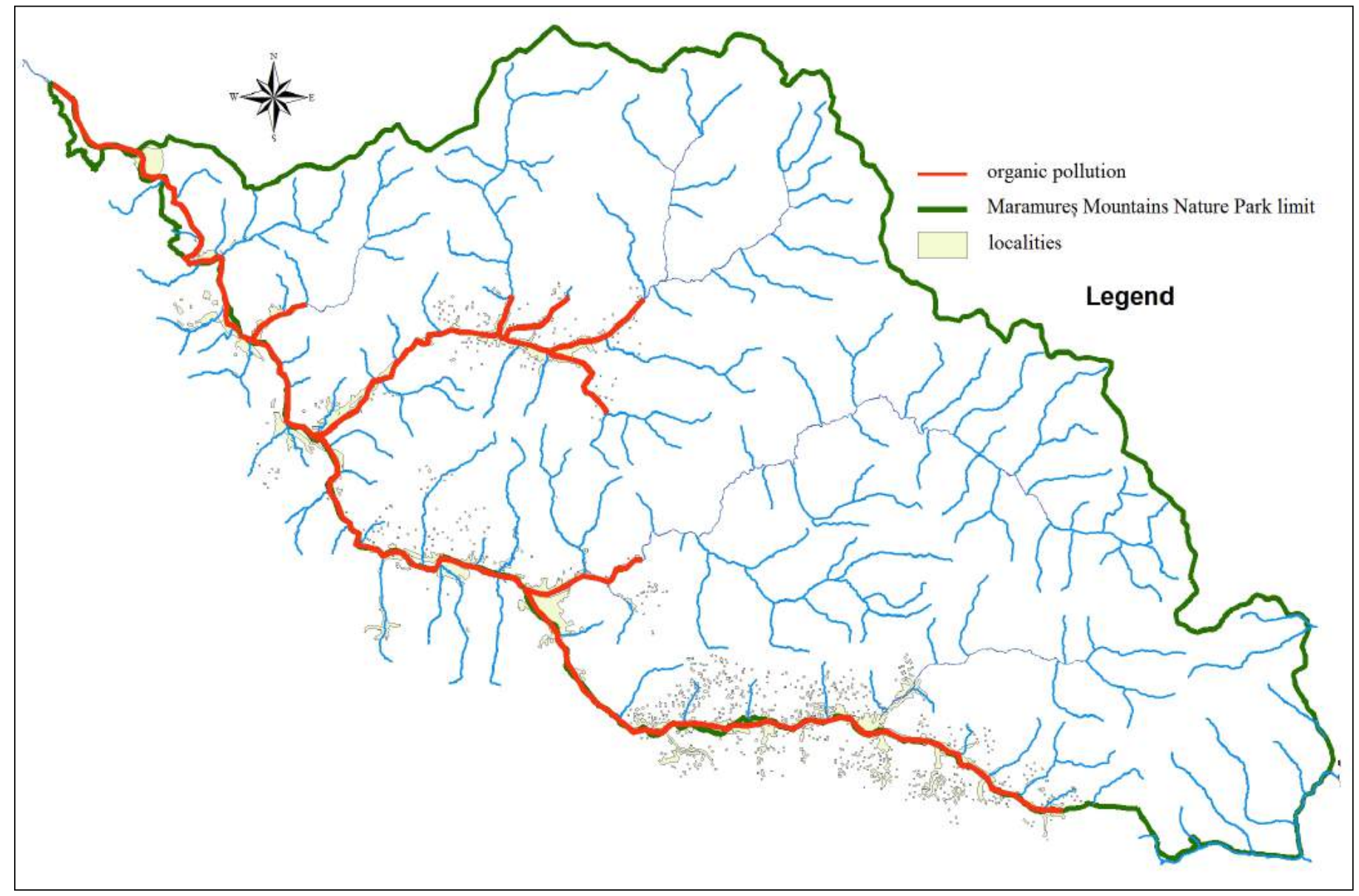

Figure 12. Lotic sectors influenced by organic pollution. 


\section{CONCLUSIONS}

Cottus gobio from the studied Vişeu Watershed is characterised by the steady populations, but it did not reach its natural maximum potential due to human activities negative effects, especially in: upper and lower Vişeu River, lower Repedea, lower Ruscova, lower Bistra and lower Frumuşeaua.

The preferred habitat for Cottus gobio is extended sufficiently within the Vişeu Watershed to conserve the present average state of the Cottus gobio studied populations.

The studied fish species can be considered in the present as a relatively rare species in the studied area but relatively good options for rehabilitation aims exist.

Among the studied streams and rivers, the conditions of the Bistra River are the most degraded as a whole from this fish species perspective, and do not meet proper habitat quality necessities for Cottus gobio species.

\section{AKNOWLEDGEMENTS}

These data were obtained in the project "Inventarierea, cartarea și evaluarea stării de conservare a speciilor de pești din Parcul Natural Munții Maramureșului (ROSCI 0124 Munții Maramureșului)/ Inventory, mapping and assessment of the conservation status of fish species of Munții Maramureșului Nature Park (ROSCI 0124 Maramureșului Mountains)". Special thanks for the continuous support of the Munții Maramureșului Natural Park Administration and Scientific Council members especially to: Bogdan C., Bucur C., Szabo B., Brener A. and Mărginean M.

\section{REFERENCES}

1. Bănăduc D., Prots B. and Curtean-Bănăduc A. (eds), 2011 - The Upper Tisa River Basin, Transylvanian Review of Systematical and Ecological Research, 11, 204.

2. Bănărescu, P. M., (1964) Pisces-Osteichthyes, Fauna R. P. R., vol. XIII., Edit. Academiei R. P. R., Bucureşti, 962.

3. Bănărescu, P. M. and Bănăduc, D, (2007), Habitats Directive (92/43/EEC) fish species (Osteichthyes) on the
Romanian Territory, Acta Ichtiologica Romanica, II: 4378.

4. Curtean-Bănăduc A., Bănăduc D. and Sîrbu I. (eds), 2008 - The Maramureş Mountains Nature Park, Transylvanian Review of Systematical and Ecological Research, 5, 222.

5. Curtean-Bănăduc A., Schneider-Binder E. and Bănăduc D., 2014 - The importance of the riverine ligneous vegetation for the Danube Basin lotic ecosystems, in Cianfaglione K. (ed.), L'importanza degli Alberi e del Bosco, Cultura, scienza e coscienza del territorio, Temi Edit., Trento, Italia, ISBN: 978-88-973772-63-9, I-II, 187-210.

6. Florea L., 2017 - The changes that occurred between 2010-2016 in the community interest fish species from protected area ROSCI0229 Siriu, Acta Oecologica Carpatica, X.II, 87-100.

7. Khoshnod Z., 2017 - Effects of environmental pllution on fish: a short review, Transylvanian Review of Systematical and Ecological Research, 19.1, 49-60.

8. Năvodaru I. and Năstase A., 2006 - Ichthyofauna of River Danube delta: Gorgova - Uzlina and Şontea Furtuna lakes complexes, Acta Ichtiologica Romanica, I, 185-202.

9. Romanescu G., Miftode D., Pintilie Mihu A., Stoleriu C. C. and Sandu I., 2016 - Water quality analysis in mountain freshwater: Poiana Uzului Reservoir in the Eastern Carpathians, Chemistry Magazine, 1, 2318-2326.

10. Staicu G., Bănăduc D. and Găldean N., 1998 - The structure of some benthic macroinvertebrates and fishes communities in the Vișeu Watershed, Maramureș, Romania, Travaux du Museum National d'Histoire naturelle Grigore Antipa, București, XL, 587-608.

11. Schneider-Binder E., 2017 - Habitats with large Bitter cress (Cardamine amara L.) in the spring area of Nera River (Semenic Mountains, Romania), Transylvanian Review of Systematical and Ecological Research, 19.1, 19-28.

12. Telcean I. C. and Bănărescu P. M., - Modifications of the fish fauna in the upper Tisa River and its southern and eastern tributaries, TISCIA monograph series, 6, 179-186. 
